\title{
An investigation into the small firm effect on the Johannesburg Stock Exchange
}

\author{
P. de Villiers, A.J. Lowings, T. Pettit and J. Affleck-Graves \\ Graduate School of Business, University of Cape Town, Rondebosch
}

Recent studies on the New York Stock Exchange have provided empirical evidence which suggests that small market capitalization firms outperform large market capitalization firms in terms of share price performance. This appears valid even after adjusting for the additional risk borne by the small firms. This has become known as the 'small firm effect' and questions the validity of many traditional pricing models such as the Capital Asset Pricing Model. In this paper, the small firm effect is examined on the Johannesburg Stock Exchange. The risk-adjusted performance of portfolios comprising large firms is contrasted with that of small firms. Three measures of size are used, namely market capitalization, asset base and traded volume. In all three cases, no evidence of a small firm effect is apparent. Indeed, if anything, the large firms appear to provide superior investment performance on the JSE.

S. Afr. J. Bus. Mgmt. 1986, 17: $191-195$

Onlangse navorsing van die New Yorkse Effektebeurs het empiriese gegewens verskaf wat toon dat klein markkapitaliseringsfirmas beter vaar as die groter firmas in terme van die prestasie van aandeelpryse. Dit skyn geldig te wees selfs nadat aanpassings gemaak is vir die addisionele risiko wat deur die klein firmas gedra word. Dit het bekend geraak as die 'kleinfirma-effek' en bevraagteken tradisionele prysvasstellingsmodelle soos die 'Capital Asset Pricing'model. In hierdie artikel word die 'kleinfirma-effek' ondersoek op die Johannesburgse Effektebeurs. Die saamgestelde portfolio's, aangepas vir risiko, word vergelyk met dié van klein firmas. Drie meetinstrumente vir grootte is gebruik, naamlik markkapitalisering, batebasis, en handelsvolume. In al drie gevalle is geen 'kleinfirmaeffek' bespeur nie. Eintlik lewer die groot firmas 'n beter investeringsprestasie op die Johannesburgse Effektebeurs. S.Afr. Tydskr. Bodryfsl. 1986, 17: 191 - 195

P. de Villers, A.J. Lowings, T. Pettit and J. Affleck-Graves* Graduate School of Business, University of Cape Town, Private Bag, Rondebosch, 7700 Republic of South Africa

-To whom correspondence should be addressed

\section{Introduction}

One of the major developments in capital market research during the past quarter of a century has been the emergence of a number of asset pricing theories. The most famous and widely applied of these theories has been the Capital Asset Pricing Model (CAPM). This theory postulates that the return that can be expected from an asset is a linear function of its covariance with the market. As a consequence the theory implies that only the covariability of the asset with the market of all possible assets is relevant for portfolio decisions. This theory has received considerable support from the academic community and has greatly influenced the way in which analysts think about security prices.

Recently, however, several studies querying the general validity of the CAPM have appeared and numerous authors have suggested that there are systematic factors other than the covariance between the asset's return and the market return that are relevant to asset pricing. For example Arbel, Carvell \& Strebel (1983) found evidence of a neglected firm effect and Basu $(1977,1983)$ found evidence of a price/ earnings effect. But, perhaps the most widely published deviation from the CAPM has been the so-called 'small firm effect'.

The small firm effect basically states that smaller firms (in terms of market capitalization) tend to earn higher returns than would be expected under the CAPM. In other words, even after allowing for their greater risk, the empirical evidence suggests that small firms earn greater returns than larger firms. The conclusion therefore is that in deriving an asset pricing model the size of the asset (in financial terms) should be taken into account as well as the covariability of the asset return with the market return.

The major studies examining the 'small firm' or 'size' effect have been conducted on the New York (NYSE) and American (AMEX) Exchanges. For example, Banz (1981) investigated the relationship between the return and market capitalization of common stocks listed on the NYSE. For the 50-year period under review, shares of firms with large market capitalizations had lower risk-adjusted returns than small market capitalization firms. However, this detected size effect was not linear in relation to the market capitalization of firms; the main effect occurred in very small firms, whilst little difference was found between average and large firms. Banz suggested that the size effect was evidence that the CAPM was misspecified.

Reinganum (1981) found that the beta risk-adjusted returns of high earnings/price ratio portfolios on NYSE-AMEX were significantly greater than the beta-adjusted returns of low earnings/price ratio portfolios. This superior performance 
tended to persist for a period which reduced the likelihood that the results were being generated by informational deficiencies. Taking the study a step further, he discovered that low market value firms produced considerably higher excess returns when compared with larger firms. He then tested whether the two observed effects were independent, and found that after controlling returns for size, the earnings/price effect was not detectable. He concluded that either the single-period, two-parameter CAPM is misspecified, or the markets were inefficient.

These two studies caused a profusion of literature attempting to either support, dispute, or explain this clear contradiction of the Efficient Market Hypothesis and/or the CAPM. Thus, for example, Roll (1981) suggested that because small firms are traded less frequently, risk measures seriously understate the actual risk of small firm portfolios.

Basu (1983) used beta and residual risk to adjust for variability, and concluded that when small firms were "correctly' assessed for risk, the abnormal returns almost disappeared. He also showed that the earnings/price ratio effect was significant even after controlling for size, which is in direct contradiction with Reinganum's findings.

Keim (1983) provided evidence that almost $50 \%$ of small firm abnormal returns are attributable to the month of January. Brown, Kleidon \& Marsh (1983) found that the size effect was unstable over time and concluded that it was sensitive to the particular period of study. Reinganum (1983), following on from the findings of Keim, suggested that the so-called 'January effect' is consistent with tax loss selling. Stoll \& Whaley (1983) confirmed the negative correlation between market value and risk-adjusted returns, but also found a similar correlation between share prices and returns. They provided further empirical evidence which suggests that transaction costs partially account for the small firm effect.

In a special issue of the Journal of Financial Economics, which reviewed the 'size effect', the editor Schwert (1983) observed that the search for an explanation of this anomaly has been unsuccessful. Attempts to modify the CAPM so as to take account of the many factors suggested by academics, have not thrown any light on the subject.

The objective of this paper is to determine whether a size effect exists on the Johannesburg Stock Exchange. This is done by examining both the traditional market capitalization measure of size and two alternatives, namely asset base and traded volume.

\section{Data}

The JSE is characterized by the dominance of mining and mining-financial shares which comprise a substantial proportion of total market capitalization. The profitability of gold mining companies depends largely on the gold price, a factor over which they can exert little influence. The gold price is established by international political and economic events that are usually divorced from the South African economy. Indeed Gilbertson \& Goldberg (1981) have confirmed that the systematic risk for the mining companies is highly correlated with the gold price. It is thus reasonable to assume that different underlying factors affect the returns of mining shares on the one hand, and industrial shares on the other.

The dominance of the overall market by this one specific type of business activity (mining), is considered to be detrimental to an objective analysis using a model assuming a homogeneous market. This is especially true when one considers the size of the gold mining companies, their non-standard accounting and tax environment, and their dependence on the fortunes of the gold price. Thus for the purposes of this study only shares from the industrial sector have been included. Accordingly, the JSE Actuaries Industrial Index was used as a market proxy in the risk-adjustment procedures.

Although ten years of share price data were available only five years of returns, 1976-1980, could be used for the comparisons of performance. This was owing to the necessity of having data both prior to, and following the year of assessment in order to estimate the risk parameters. That is, it was considered important that the parameter estimation took place outside of the period of comparison. Failure to do this could lead to a bias in the results as is well-documented in the literature (for example, Banz, 1981). The particular period was selected because of the availability of reliable data.

In 1980, the industrial sector consisted of 306 listed firms, of which 44 were holding companies. The balance of the companies were spread across the 18 different subsectors. Total market capitalization of the industrial sector was R20 063 million with Holding Companies and Chemicals accounting for $25 \%$ and $19 \%$ of market capitalization, respectively. It should be noted that of the five years under review, only 1976 produced negative market returns. The positive returns for the balance of the four years, peaked in 1979.

Weekly data were acquired for all 286 shares continuously listed on the industrial sector for the ten-year period, January 1973 - December 1982. However, certain of these had to be excluded from the analysis for the following reasons. Firstly, trading data of a minimum of six years were required for return and risk parameter estimation; 63 shares did not meet this criteria. Secondly, shares which traded in less than $25 \%$ of the available weeks were excluded to avoid the effects of thin trading and zero returns (eight shares fell into this category). Finally, a further seven shares were discarded owing to a lack of financial or record information. The final data set was thus limited to the returns from 208 industrial firms. An examination of those shares discarded, did not indicate a predominance of either a particular company size or sector type.

It should be noted that it is possible that a survival bias may have been introduced, as companies that were acquired, delisted or filed bankrupt have been excluded.

\section{Portfolio selection}

In determining the size criteria to employ for portfolio selection, Banz, Reinganum and most of the other researchers of the small firm effect have used market capitalization as the relevant criteria. However, this study was extended so as to consider the influences of 'Asset Base' and 'Marketability', as well as the influence of market capitalization.

Market capitalization was calculated as the average of the share's high and low prices during a year, multiplied by the number of shares in issue. Asset base was calculated for each company in the sample as net working capital plus all fixed and other assets, i.e. total capital employed, as at the financial year end. As these represent book values and not market values it is not felt that any serious effects from differing year ends will result. The marketability factor was calculated by multiplying the volume traded by the closing price for each week of the year, to give an estimate of the annual traded turnover for each share. This was felt to provide some measure of the perceived popularity and desirability of a share. In addition, the relative ease and ability of a security to trade freely on the open market could be an attribute which is important to investors. 
All of the firms in the sample were then ranked according to each of the above three criteria. Specific limits were quantified in order to separate large and small firms from the rest of the market. Portfolios were selected from the upper and lower quintiles of the sample. The rand values of these limits were:

$\begin{array}{lcc}\text { Large firms } & 1976 & 1980 \\ \text { Market capitalization } & \text { R20m } & \text { R 60m } \\ \text { Asset base } & \text { R50m } & \text { R100m } \\ \text { Marketability } & \text { R80m } & \text { R550m } \\ \text { Small firms } & 1976 & 1980 \\ \text { Market capitalization } & \text { R2,4m } & \text { R 5m } \\ \text { Asset base } & \text { R4,9m } & \text { R10m } \\ \text { Marketability } & \text { R3,5m } & \text { R30m }\end{array}$

(By way of comparison, small firms on the NYSE used by Banz had an upper limit of $\$ 65$ million.)

Most of the portfolios contained 10 shares, but 20 share portfolios were also tested where possible. Firms were ranked according to the three size criteria, for each of the five years of assessment. All portfolios were reconstructed at the beginning of each year to ensure that the specific character of a portfolio did not become distorted over time.

\section{Methodology}

To allow the performance of small and large firm portfolios to be measured on a comparable basis, the following approach was adopted. The annual excess returns for each portfolio were calculated, and then adjusted for risk. Results of the small and large portfolios were then compared over the fiveyear period, to determine whether superior performance was evident. A consistent pattern of significantly greater returns by one portfolio, either small or large, would tend to indicate an anomaly peculiar to that portfolio type.

Three methods of risk adjustment were considered: Sharpe's Reward to Variability Ratio, Treynor's Index and Jensen's Abnormal Performance Index. For each of these three methods, monthly returns for five years were used to estimate the relevant risk parameters. However, the 60 months were not taken over a continuous period. Instead, when assessing the performance in a particular year, the three years prior to, and the two years following that year were used to estimate the parameters. Thus, the actual year under study was not included in the estimation procedure.

The monthly excess share returns of each security included in a portfolio were calculated (for use in the risk-adjustment computations) as follows:

$R_{j t}=\ln \left(P_{t} / P_{t-1}\right)-R_{f}$

where $R_{j t}=$ excess return on security $j$ during period $t$; $\boldsymbol{P}_{\boldsymbol{t}}=$ share price at end of period $t ; \boldsymbol{P}_{t-1}=$ share price at end of previous period; and $R_{f}=$ risk-free rate.

Portfolios were constructed with equal rand amounts invested in each share.

The beta and alpha parameters were calculated for each portfolio using the familiar market model:

$\left(R_{p}-R_{f}\right)=a+B\left(R_{m}-R_{f}\right)+e_{p}$

where $R_{p}=$ return on the portfolio; $R_{m}=$ return on the market portfolio; $e_{p}=$ a random error term; $R_{f}=$ riskless rate of interest; $B=\operatorname{cov}\left(R_{p}, R_{m}\right) / \operatorname{var}\left(R_{m}\right)$; and $a=$ intercept term.

The actual yearly excess returns for each security within a portfolio were calculated for each year as follows:
$R_{f t}=\ln \left(C F_{t} / C F_{t-1}\right)-R_{f}$

where

$C F_{t}=P_{t}(1-B)-B C ;$

$C F_{t-1}=P_{t-1}(1+B+M S)+B C$;

and $C F_{t}=$ cash flow (in) on sale; $C F_{t-1}=$ cash flow (out) on purchase; $P_{t}=$ price of security at end of December for year under consideration; $P_{t-1}=$ price of security at the end of December of the previous year; $B=$ Brokerage fee $(0,85 \%) ; B C=$ Basic brokerage charge $(0,5 \mathrm{c} /$ share $) ; M S=$ Marketable Securities Tax (1\%); and $R_{f}=$ Annual risk-free interest rate ( 360 day Treasury Bill Rate).

The actual return on the portfolio was the arithmetic mean of the individual security returns.

The three risk-adjustment procedures were as follows. 1. The Sharpe Index (Sharpe, 1970:153).

Sharpe's Reward to Variability Ratio was used for each portfolio return as follows:

$S_{p}=R_{p} / S D_{p}$

where $S_{p}=$ risk-adjusted returns on portfolio $p ; R_{p}=$ excess yearly returns (actual); and $S D_{p}=$ standard deviation of portfolio returns.

2. Treynor's Index (Treynor, 1965).

$T_{p}=R_{p} / B_{p}$

where $B_{p}=$ the estimated portfolio-specific risk factor for the year under consideration.

3. Jensen's Abnormal Performance Index (Jensen, 1968).

$J_{p}=R_{p}-B_{p} . R_{m}$

where $R_{m}=$ rate of return on the market portfolio.

It should be noted that both the Treynor and Jensen measures rely on the ability to obtain reliable beta estimates. This may prove difficult for a number of securities quoted on the JSE. For this reason the Sharpe performance measure has also been included. However, it should also be borne in mind that the betas used in the portfolio measure are portfolio betas which can be expected to be much more stable than individual betas.

\section{Results}

An initial examination of the small firm effect on the JSE was performed by including only shares ranked small on all three size criteria in the 'small share' portfolio. Similarly, only shares ranked large on all three criteria were included in the 'large share' portfolio. The results are summarized in Table 1.

It can be observed that, on average, the performance of the large firm portfolios is superior with respect to all three performance measures.

These results are clearly inconsistent with the hypothesis that a small firm effect exists on the JSE. However, it is possible that the above results are biased in that the included firms had to be small or large in terms of all three of the

Table 1 Average risk-adjusted returns - three criteria combined

\begin{tabular}{lccc}
\hline $\begin{array}{l}\text { Performance } \\
\text { measure }\end{array}$ & Large firms & Small firms & Difference \\
\hline $\mathbf{T}$ & 13,0 & $\mathbf{6 , 6}$ & 6,4 \\
$\mathbf{S}$ & 2,4 & $-1,3$ & 3,7 \\
$\mathbf{J}$ & $-1,2$ & $-6,5$ & 5,3 \\
\hline
\end{tabular}


criteria examined in this paper. It is conceivable that the small firm effect might exist for only one of the criteria but that this has been hidden by the confounding effect of the two additional criteria which each firm was required to satisfy.

Accordingly, it was decided to examine the behaviour of portfolios chosen on the basis of each criteria individually. Thus, 'small' firms were selected when ranked low on the isolated criterion, with the selection process reversed for large firm portfolios. In order to avoid an overlap in the small portfolios chosen according to each of the three criteria (and a similar overlap in the large portfolios) it was decided to include only securities in a portfolio representing a specific smallness criteria if that security was not small on the other two criteria. For example, for the market capitalization small portfolio only securities with small market capitalizations but relatively large asset bases and traded volumes were included. Similarly, for the large market capitalization portfolio only securities with large market capitalization but relatively small asset bases and traded volumes were included. In this way it was hoped to isolate a pure small criteria effect. The results for each criteria are discussed individually.

\section{Market capitalization}

The results obtained for portfolios selected on the basis of market capitalization are summarized in Table 2.

This table confirms the previous finding that there appears to be no evidence of a 'small firm' effect on the JSE. Indeed, the reverse appears to apply as the large firm portfolios outperformed the small firm portfolios on average over the five-year period for all three measures of performance. On examination of the individual years, it is apparent that, using the Sharpe measure, the large firms outperformed the small firms in each of the five years examined. Using the Treynor and Jensen measures, the large firms outperform the small firms in each of the first three years, usually by a substantial margin. In the last two years, the converse applies for these two measures with the small firms outperforming the large firms. However, in these cases the differential is extremely small.

It is therefore difficult to conclude other than that there appears to be a large firm effect on the JSE when the selection criteria is based on market capitalization. These results are contrary to the findings on the NYSE where small firms performed better in the majority of years studied. Finally, it is pertinent to note that problems associated with thinly traded securities (see the section on data selection) are almost exclusively related to 'small' firms. The effect of thin trading would be to artificially reduce the beta estimate, thereby increasing the risk-adjusted return on the thinly traded portfolio. Thus, any further attempts made to eradicate thin trading effects would be more likely to increase the superiority of the large firm portfolios rather than to reduce their performance.

\section{Asset base}

In Table 3 a summary is provided of the performance of both large and small firm portfolios where the selection is based on asset size.

As can be seen, this table provides some support for the small firm effect in that, on average, the small firm portfolios outperformed the large firm portfolios over the five-year period. However, this result was not consistent over all years individually, with the small asset base portfolios only outperforming the large asset base portfolios in three of the five years (for all three measures of performance). These results cannot therefore be construed as providing support for the small firm effect on the JSE. The most rational conclusion would be that asset size does not appear to be a factor affecting relative performance on the JSE.

Table 2 Yearly risk-adjusted returns - market capitalization

\begin{tabular}{|c|c|c|c|c|c|c|c|c|c|c|c|c|}
\hline \multirow{2}{*}{$\begin{array}{l}\text { Performance } \\
\text { measure }\end{array}$} & \multicolumn{2}{|c|}{1976} & \multicolumn{2}{|c|}{1977} & \multicolumn{2}{|c|}{1978} & \multicolumn{2}{|c|}{1979} & \multicolumn{2}{|c|}{1980} & \multicolumn{2}{|c|}{$\begin{array}{c}\text { Average } \\
1976-1980 \\
\end{array}$} \\
\hline & Large & Small & Large & Small & Large & Small & Large & Small & Large & Small & Large & Small \\
\hline $\mathbf{T}$ & $-34,6$ & $-80,7$ & 34,6 & $-39,7$ & 61,1 & 26,6 & 52,2 & 53,5 & 48,4 & 49,0 & 32,3 & 1,7 \\
\hline $\mathbf{S}$ & $-4,4$ & $-6,7$ & 4,0 & $-4,1$ & 7,7 & 3,1 & 7,2 & 5,3 & 6,3 & 5,4 & 4,2 & 0,6 \\
\hline J & $-9,2$ & $-41,5$ & 14,8 & $-33,5$ & 19,5 & 0,7 & 3,1 & 4,9 & 27,4 & 29,7 & 11,1 & $-7,9$ \\
\hline
\end{tabular}

Table 3 Yearly risk-adjusted retums - asset base

\begin{tabular}{|c|c|c|c|c|c|c|c|c|c|c|c|c|}
\hline \multirow{2}{*}{$\begin{array}{l}\text { Performance } \\
\text { measure }\end{array}$} & \multicolumn{2}{|c|}{1976} & \multicolumn{2}{|c|}{1977} & \multicolumn{2}{|c|}{1978} & \multicolumn{2}{|c|}{1979} & \multicolumn{2}{|c|}{1980} & \multicolumn{2}{|c|}{$\begin{array}{c}\text { Average } \\
1976-1980\end{array}$} \\
\hline & Large & Small & Large & Small & Large & Small & Large & Small & Large & Small & Large & Small \\
\hline$T$ & $-47,8$ & $-59,6$ & 5,7 & $-73,3$ & 24,4 & 6,9 & 42,5 & 61,1 & 37,3 & 157,3 & 12,4 & 18,5 \\
\hline $\mathbf{S}$ & $-6,1$ & $-4,5$ & 0,8 & $-6,2$ & 3,9 & 0,6 & 4,5 & 4,6 & 5,8 & 8,7 & 1,8 & 0,6 \\
\hline $\mathbf{J}$ & $-25,5$ & $-17,8$ & $-0,3$ & $-38,9$ & $-1,2$ & $-7,9$ & $-22,8$ & 5,4 & 25,6 & 31,9 & $-4,8$ & $-5,5$ \\
\hline
\end{tabular}

Table 4 Yearly risk-adjusted retums - marketability

\begin{tabular}{|c|c|c|c|c|c|c|c|c|c|c|c|c|}
\hline \multirow{2}{*}{$\begin{array}{l}\text { Performance } \\
\text { measure }\end{array}$} & \multicolumn{2}{|c|}{1976} & \multicolumn{2}{|c|}{1977} & \multicolumn{2}{|c|}{1978} & \multicolumn{2}{|c|}{1979} & \multicolumn{2}{|c|}{1980} & \multicolumn{2}{|c|}{$\begin{array}{c}\text { Average } \\
1976-1980\end{array}$} \\
\hline & Large & Small & Large & Small & Large & Small & Large & Small & Large & Small & Large & Small \\
\hline $\mathbf{T}$ & $-27,0$ & $-76,7$ & $-11,6$ & 0,1 & $-0,8$ & 33,5 & 41,7 & 65,2 & 39,9 & 24,9 & 8,4 & 9,4 \\
\hline $\mathbf{S}$ & $-3,7$ & $-6,6$ & $-1,7$ & 0 & $-0,1$ & 3,7 & 5,9 & 8,2 & 5,4 & 2,8 & 1,2 & 1,6 \\
\hline J & $-5,6$ & $-25,4$ & $-16,5$ & $-3,6$ & $-20,9$ & 5,6 & $-3,3$ & 13,0 & 21,4 & 9,7 & $-5,0$ & $-0,1$ \\
\hline
\end{tabular}




\section{Marketability (traded value)}

The results obtained when selection was based on traded value are summarized in Table 4.

Once again the results provide no evidence of a small firm effect on the JSE. Indeed, the results for this size criteria vary according to the performance measure used. Thus, on average over the five years the large firm portfolios performed better than the small firm portfolios when using the Jensen or Treynor measures. However, the reverse occurs when using the Sharpe measure. In addition, the performance from year to year is so varied as to preclude strong support for either a large or small firm effect. Thus, as in the case of asset size, traded value does not appear to be a significant factor affecting relative performance on the JSE.

\section{Conclusion}

This paper has reviewed the relative performance of small and large firms on the JSE.

The studies on the NYSE have indicated that low market capitalization firms have higher beta-adjusted returns than large market value firms. The results of this study indicate that no such effect is evident in the industrial sector of the JSE. Indeed, if anything, a large firm effect is evident, as the returns obtained on portfolios chosen from the large market capitalization companies outperformed small market capitalization portfolios in most of the five years examined.

Two other size criteria were also examined, namely asset size and traded value. In both cases the results did not indicate the presence of either a small or large firm effect.

Thus, the overall conclusion of the study is that a small firm effect does not exist on the JSE. There are many possible reasons why such a small firm effect is not present on the JSE. For example, it may be due to the dominance of institutional investors on the JSE and the weight of funds arguments resulting from the inability of most institutions to invest abroad. Alternatively it may be due to the extensive presence of cross holdings on the JSE. Yet another possible explanation is that it is due to the relative low turnover rate on the JSE when compared to other exchanges. Which of these reasons is correct or indeed whether other factors cause the absence of a small firm effect remains an open research question.

\section{References}

Arbel, A., Carvell, S. \& Strebel, P. 1983. Giraffes, Institutions and Neglected Firms. Fin. Anal. J.; May-June, 57-63.

Banz, R.W. 1981. The Relationship between Return and Market Value of Common Stock. J. Fin. Econ, vol. 8, 3-18.

Basu, S. 1977. Investment Performance of Common Stocks in Relation to their Price-earnings Ratios: a Test of the Efficient Market Hypothesis. J. Fin., vol. 32, 663-682.

Basu, S. 1983. The Relationship between Earnings' Yields, Market Value and Return for NYSE Common Stocks. J. Fin. Econ., vol. $10,129-156$.

Brown, P., Kleidon, A.W. \& Marsh, T.W. 1983. New Evidence on the Nature of Size-Related Anomalies in Stock Prices. $J$. Fin. Econ., vol. 10, 33-56.

Gilbertson, B. \& Goldberg, M. 1981. The Market Model and the Johannesburg Stock Exchange. Invest. Anal. J., No. 17, $40-42$.

Jensen, M.C. 1968. The Performance of Mutual Funds in the Period 1945-1964. J. Fin., vol. 23, 389-416.

Keim, D.B. 1983. Size-Related Anomalies and Stock Return Seasonality. J. Fin. Econ., vol. 10, 13-32.

Reinganum, M.R. 1981. Misspecification of Capital Asset Pricing: Empirical Anomalies Based on Earnings' Yields and Market Values. J. Fin. Econ., vol. 8, 19-46.

Reinganum, M.R. 1983. The Anomalous Stock Market Behaviour of Small Firms in January. J. Fin. Econ., vol. 10, 89-104.

Roll, R. 1981. A Possible Explanation of the Small Firm Effect. J. Fin., vol. 36, 879-888.

Schwert, G.W. 1983. Size and Stock Returns, and other Empirical Regularities. J. Fin. Econ., vol. 10, 3-12.

Sharpe, W.F. 1970. Portfolio Theory and Capital Markets. New York: McGraw-Hill, 316 p.

Stoll, H.R. \& Whaley, R.E. 1983. Transaction Costs and the Small Firm Effect. J. Fin. Econ., vol. 10, 57-79.

Treynor, J.L. 1965. How to Rate Management of Investment Funds. Harv. Bus. Rev., vol. 43, 63-75. 